\title{
Review on Genetic Variation in Potato (Solanum Tuberosum L.) for Processing Quality Traits
}

\author{
Ebrahim Seid Hussen \\ Ethiopia Institute of Agricultural Research (EIAR), Holetta Agricultural Research Center (HARC), P. O. Box: \\ 2003, Addis Ababa, Ethiopia
}

\begin{abstract}
Potato (Solanum tuberosum L.) is a versatile food crop and a source of cheap human diet in many countries. It can be used as fresh products and commercially processed foods such as French fries and chips. The genetic makeup is the most important factor that influences quality attributes. Traits that are genetically controlled can be grouped into biological traits (proteins, carbohydrates, vitamins, minerals, reduced amounts of toxic glycoalkaloids), sensorial (flavour, texture, colour), and industrial traits (tuber shape and size, dry matter content, cold sweetening, oil absorption, starch quality). Therefore, the breeding work can successfully meet the needs of a changing and demanding the processing quality. In this review paper discusses some breeding strategies that can be used to create genetic variability and to help the selection programs for internal and external quality traits in potato for processing aspect. The genetic diversity of potatoes grouped in wild and cultivated potatoes. The cultivated potatoes Solanum tuberosum are tetraploid $(2 n=4 x=48)$ due to high specific gravity. Varieties with long tubers are used for French fries, while varieties with round tubers are preferred for crisps. A potato variety with dry matter content below $19.5 \%$ and $20 \%$ is not acceptable for French fries and for chips, respectively. Similarly, a dry matter content of more than $25 \%$ is not suitable for French fries manufacturing. The level of reducing sugars that are generally acceptable for chips processing is $0.2-0.3 \%$ and for French fries is $0.3-0.5 \%$. Generally, selection of varieties should not be limited only for high yield, but also for internal (specific gravity, dry matter, starch contents) and external quality (tuber shape, eye depth, tuber fresh color and tuber skin color) of tubers.
\end{abstract}

Keywords: Genetic Variation, Processing quality, Tuber quality, Chips, French fries

DOI: $10.7176 / \mathrm{JNSR} / 9-12-05$

Publication date: June $30^{\text {th }} 2019$

\section{Introduction}

Potato (Solanum tuberosum L.) is an important vegetable crop throughout the world because of its high production, high calorific value, low cost and easy to cook methods (Shrisat and Thomas 1998). Potato is a nutritious vegetable containing $16 \%$ carbohydrates, $2 \%$ proteins, $1 \%$ minerals, $0.6 \%$ dietary fiber and negligible amount of fat (Gumul et al. 2011). The potato plant is a versatile food crop and a cheap source of food in many countries. It is the third most important food crop in terms of consumption in the world after rice and wheat (Birch et al. 2012; Hancock et al. 2014). The high yield potential of potato and its plasticity to environmental regimes makes it as one of the best crops for food and nutrition security in Eastern Africa (Kyamanywa et al. 2011). On average, the dry matter content of potato tuber is $20 \%$ and the large proportion (60 to $80 \%$ ) of dry matter is composed of starches, making it a food rich in carbohydrates (Lutaladio and Castaidi 2009). Besides being rich source of carbohydrates, potato also contains some health promoting compounds such as phenolic acids, ascorbic acid and carotenoids (Ezekiel et al. 2013).

Potatoes are consumed either directly or after processing in the form of chips and French fries, mashed and canned potatoes. Now a day the use of potato in processed forms such as French fries and chips is rapidly growing. Such kind of processed products cannot be made from any potato varieties. The tuber specific gravity, dry matter and starch contents of a variety are critical features determining the quantity and quality of both products of industries (starch) and processed foods (French fries and chips) (Hassanpanah et al. 2011; Kaur and Aggarwal 2014). Different cultivars have different uses. Cultivars with low dry matter content are used for fresh market, while those with long tuber and dry matter content of $>19.5$ percent are suitable for French fries (Kirkam 2007). Thus, the quality of potato tuber determines the specific end to which a given variety will be used or where it will end up. Quality parameters of potato change according to the specific market utilization types, and are often referred to two major categories. The first category groups "external quality", aspects comprises skin colour, tuber size, and tuber shape and eye depth. These traits are deemed very important for fresh consumption and are most likely influence consumer's choice. The second category comprises "internal quality" aspects and includes nutritional properties, processing quality, dry matter content, flavour, sugar and protein content, starch quality, type and amount of glycoalkaloids (Carputo et al. 2004). Therefore, selection of varieties should not be limited for high yield, but also for internal and external quality of tubers.

There are several factors affecting tuber quality. They include the genetic makeup of the cultivar, crop maturity, agronomic practices, environmental conditions, storage temperatures, pests and diseases. The genetic makeup is the most important factor that influences quality attributes (Carputo et al. 2004). Traits that are 
genetically controlled can be grouped into biological traits (proteins, carbohydrates, vitamins, minerals, reduced amounts of toxic glycoalkaloids), sensorial (flavour, texture, colour), and industrial traits (tuber shape and size, dry matter content, cold sweetening, oil absorption, starch quality). Many authors reported the presence of significant differences among potato cultivars for these tuber quality traits (Asmamaw et al. 2010; Elfnesh et al. 2011; Hassanpanah et al. 2011; Tesfaye et al. 2012a; Kaur and Aggarwal 2014; Ismail et al. 2015) suggesting the significance of testing potato genotypes for these quality traits to benefit producers, processors and consumers. Studying the genetic variability present among different potato genotypes for a given character is a basic prerequisite to design systematic breeding methods. Information on the genetic diversity in a population and genetic variability components play a vital role for the success of any crop improvement program. Knowledge of the genetic diversity of a potato population is a useful tool for an efficient choice of parents for hybridization that aimed at developing high yield cultivars with desirable features (Arslanoglu et al. 2011).

According to Brown (2005), tuber quality is one among the most important features of potato production now a day. Breeding for resistance to late blight and high yield have been the main priorities of Ethiopia's potato breeding program in the past years. A lot of efforts have been made and several improved varieties with these characteristics have also been released. However, small scale potato chips processors are flourishing in cities and big towns (Elfnesh et al. 2011). Potato chips and French fries are commonly found in Hotels, restaurants, supermarkets and small shops. In addition, the country has a potential in producing potatoes to supply large scale potato processing industries that might not be far from establishment (Wassu 2016). In this review paper we outline some breeding strategies that can be used to create genetic variability and to help the selection programs for internal and external quality traits in potato for processing aspect.

\section{LITERATURE REVIEW}

\subsection{Origin, Distribution and Importance of Potato}

The Andes are a center of origin and diversity for many crop species, including the potato. Potatoes were domesticated between 10,000 - 7,000 years ago, likely around Lake Titicaca, in the Andes between Peru and Bolivia (Spooner et al. 2005). The first record of cultivated potatoes outside South America is their introduction in 1567 from Gran Canaria in the Canary Islands to Antwerp in Belgium (Hawkes and Francisco-Ortega 1993). These authors concluded that the potato was first introduced from South America into the Canary Islands around 1562, and from there to mainland Europe.

Potato is a carbohydrate rich crop that provides significant amounts of protein, with a good amino acid balance, vitamins $\mathrm{C}, \mathrm{B} 6$ and $\mathrm{B} 1$, minerals potassium, phosphorus, calcium and magnesium and micronutrients iron and zinc. The tuber is high in dietary fiber, especially when eaten unpeeled with its skin, and is rich in antioxidants comprising polyphenols, carotenoids, and vitamin C. Fresh potatoes are virtually free of fat and cholesterol (Storey 2007; Camire et al. 2009). The nutrient-rich potato can contribute to improved diets, thus to reducing mortality rates caused by malnutrition especially among women and children and can improve food security and health. Increases in potato yields are essential to improve the livelihoods and food security of poor farmers (Cuesta 2013).

\subsection{Genetic Variation in Potato}

The germplasm base of potato is comprised of primitive indigenous landraces and wild Solanum species (Ovchinnikova et al. 2011). Advances in molecular techniques have provided greater insight into the taxonomic relationships of potato and there are 100 wild species and four cultivated species (Spooner et al. 2007). Potato is a highly heterozygous out crossing species which is asexually propagated, via tubers, for food production and germplasm maintenance. Potato genetic variation vary in ploidy levels (diploid to hexaploids) and show a high degree of diversity in tuber size, shape, skin and flesh colour, storage ability and cooking quality (Andre et al. 2007). In addition to the indigenous and primitive landraces, there are a number of wild species of the genus Solanum with various ploidy levels that can be used as new sources of genetic diversity, for a range of economically important traits, to develop new potato varieties (Bradshaw and Ramsay 2005). The genetic diversity of potatoes Solanum Section Petota (Solanaceae) may be grouped in wild and cultivated potatoes; this last could be grouped in native potatoes and improved potatoes. The cultivated potatoes Solanum tuberosum are tetraploid $(2 \mathrm{n}=4 \mathrm{x}=48)$, while the native are highly diverse, diploids $(2 n=2 x=24)$, triploids $(2 n=3 x=36)$, tetraploids $(2 n=4 x=48)$, pentaploids $(2 \mathrm{n}=5 \mathrm{x}=60)$ and hexaploids $(2 \mathrm{n}=6 \mathrm{x}=72)$ (Huaman and Spooner 2002).

Wild Solanum species are found in 16 countries, from the southwestern United States to central Chile (Spooner and Salas 2006). The greatest diversity of species is found in central Mexico at $20^{\circ} \mathrm{N}$, and in the southern hemisphere, especially in the highlands of the Andes between $8^{0}$ and $20^{\circ} \mathrm{S}$ (Hijmans and Spooner 2001). Wild potatoes grow from sea level to $4300 \mathrm{~m}$, but are most commonly found at altitudes of 2000-4000m. Collectively, these species represent a more diverse and accessible germplasm resource than in any other crop (Hawkes 1990). These wild species contain genes encoding numerous traits not found in cultivars and represent an especially rich source of disease resistance and tuber quality genes (Spooner and Bamberg 1994; Jansky 2000). About 64\% of wild Solanum species are diploid $(2 x=24)$, with most of the remaining species tetraploid $(4 x=48)$ or hexaploid 
$(6 \mathrm{x}=72)$ (Hijmans et al. 2007). Therefore, use of wild species for breeding and selection program is important to develop widely adaptable varieties that are disease resistant and have better tuber quality traits.

\subsubsection{Genetic Variation for Tuber Quality Traits}

Analysis of tuber traits that make up the quality aspect of potato tubers or the underlying genetics is very complex. Of all the traits breeders are working on, breeding for quality traits is often the most complex than resistance breeding. For quality traits the observed phenotype is often results of interactions of a multitude of genes acting together in complete metabolic pathways, like in the case of cold sweetening where both the starch biosynthesis as well as the starch degradation pathway play a role in the observed variation for cold sweetening (Brown 2005). The presence of wide variations among varieties for tuber specific gravity, dry matter and starch contents indicates that genetic factor is important to influence the tuber internal quality traits (Wassu 2016). Breeding for quality requires a basic understanding of the pathways underlying the trait of interest. Furthermore, identifying the genes involved and how they function and are regulated within the biosynthetic routes is an important prerequisite to understand the biology of phenotype expression. To this effect, it is crucial to identify the existing allelic diversity that generally governs the transcription and ultimately expression of these useful traits.

\subsection{Tuber Quality Traits in Potato}

In the case of potato tuber, quality can be defined as the sum of favorable characteristics of the tuber, which is a subjective and dynamic concept that depends on consumer's life styles tradition, food habits and the industrial process used (Richards et al. 1997). A complex set of external and internal quality traits are required for fresh and processed potatoes. External quality traits include tuber shape, eye depth, skin and flesh color (Jansky 2009). Dormancy and greening are additional important quality traits (Werij 2011). These characters are especially important for fresh market potatoes, but they may also impact processing quality. Internal quality includes the content of dry matter, reducing sugar, glycoalkaloids, enzymatic discoloration and nutritional quality (Storey 2007). Tuber shape is a collection of many characters, that considers the length/width ratio for describing the overall shape, and it varies from compressed/round to long tubers (Van Eck 2007; Werij 2011). The shape of the tuber is one of the most eye-catching traits of the potato crop (Van Eck et al. 1994). Eye depth is an important trait of tuber quality because deep eyes affect the appearance of tubers and add to the cost of peeling in processing factories ( $\mathrm{Li}$ et al. 2005). It also increases peeling waste during processing finally reducing the yield of processed products. One of the most easily noticeable traits of potato tubers is the skin color. This character ranges from white-cream to blackish.

\subsubsection{Tuber Quality Traits for Table Purpose}

Quality characteristics are broadly defined as those traits that determine the degree to which tubers are fit-for intended end use (Simmonds 1979). Consumers requirements for the fresh market are often associated with the tuber morphological features (shape, depth of eyes, skin and flesh color), together with greening, dormancy and taste. Furthermore these traits are also important for farmers and traders. These characters determine acceptability of the tuber. High tuber yield which is one of the most important selection criteria of the breeding program for the development of new potato varieties elsewhere is also an important selection criterion for farmers in Ethiopia. In the case of potato, several traits influence the preference of the farmers, traders and consumers. These traits are mainly agronomic and tuber quality related characteristics. Consumers' requirements regarding tuber quality for fresh market potatoes are often associated with the visual characteristics of the product such as shape, tuber size, skin and flesh color and appearance of the tuber (Storey 2007). An important character that affects the taste and safe consumption of potato for the fresh market is total glycoalkaloid content in tubers, which is an important criterion of selection in the potato-breeding scheme, since glycoalkaloids can be passed to progenies during breeding (Kozukue et al. 2008).

Most of consumers prefer a variety suitable for several types of food preparation (mashed potato, soups, fries, salad or cooked). However, to get a variety with all these characteristics is difficult because each food preparation has specific tuber quality requirements. For example potato varieties for frying purpose needs to have high dry matter content (DMC) and low reducing sugar content (Storey 2007), while, potatoes for soups or stews should maintain their consistence after cooking hence a low dry matter content potato variety is required (Taylor et al. 2007).

\subsubsection{Tuber Quality Traits for Processing}

Eye depth and tuber shape are critical aspects of selection for the processing market. Varieties with long tubers are used for French fries, while varieties with round tubers are preferred for crisps (Van Eck et al. 1994; Kirkman 2007). To minimize waste during peeling shallow eyes are the ideal for the processing purpose (Li et al. 2005). Tuber specific gravity, which is a measure of dry matter content, is a critical processing quality trait. Cultivars with high dry matter are required for the production of fries, chips, and starch. Asmamaw et al. (2010), Elfnesh et al. (2011), Tesfaye et al. (2012b) and Ismail et al. (2015) reported that dry matter content and specific gravity of tubers are significantly influenced by the interaction effect of growing environment and cultivars. High specific gravity is often noted in tetraploid clones derived from sexual polyploidization in which the diploid parent contains 
wild or cultivated potato relatives (Buso et al. 2000).

Dry matter content is also the other critical character highly demanded by the processing industry. It is a measure of the tuber internal quality. Starch is the principal compound, which is a polygenic trait and the effects are located on all chromosomes (Van Eck 2007; Werij et al. 2012). Kirkman (2007) reported that a potato variety with dry matter content below $19.5 \%$ and $20 \%$ is not acceptable for French fries and for chips, respectively. Similarly, a dry matter content of more than $25 \%$ is not suitable for French fries manufacturing. Dry matter content is affected by environmental factors during growth of the crop, such as solar radiation, soil temperatures, soil moisture, fertilizers and haulm killing. In general, cold climate and short growing seasons reduce dry matter content, whereas the contrary occurs in warm, sunny locations with long growing seasons and an adequate water supply (Hughes 1974; Haverkort 2007).

The level of sugars in potato tuber is an important factor affecting quality in potatoes, because at high temperatures, reducing sugars such as glucose and fructose interact with free amino acids in the maillard reaction, which affect the color and flavor. It has also been related to acrylamide formation in fried products (Kumar et al. 2004). Sugar levels in a potato tuber are conditioned by several factors, which include genotype, the environmental conditions and cultural practices during growth, and several post-harvest factors including storage (Kumar et al. 2004). Elfnesh et al. (2011) reported that cultivar, growing environment and their interaction did not significantly affect the tuber reducing sugar content. The main sugars present are the monosaccharides, fructose $(0.15-1.5 \%)$ and glucose $(0.15-1.5 \%)$, which are reducing sugars, and sucrose $(0.4-6.6 \%)$, a non-reducing disaccharide (Storey 2007).

The level of reducing sugars that are generally acceptable for chips processing is $0.2-0.3 \%$ and for French fries is $0.3-0.5 \%$. The sugar content of the harvested crop is also important for the fresh market, and sucrose levels above $1 \%$ fresh weight are reported to give an unacceptably sweet taste to the boiled potatoes (Storey 2007). Another important trait is enzymatic discoloration, which is a widespread phenomenon that causes loss of quality and is of major economic importance, that is caused by the oxidation of phenolic compounds by the enzyme tyrosinase (polyphenol oxidase, PPO) to quinones, followed by transformation of the quinones to dark pigments (Friedman 1997). This discoloration results in deterioration of flavor, color and nutritional quality that produce considerable economic losses for the food processing and retail industry (Werij et al. 2007).

For French fry and potato chips industries, breeding for reduced sugar content, acceptable specific gravity, dry matter and starch contents is a primary goal. Therefore, selection of varieties should not be limited only for high yield, but also for internal (specific gravity, dry matter, starch contents) and external quality (tuber shape, eye depth, tuber fresh color and tuber skin color) of tubers.

\section{Conclusion}

Potato is versatile food crop and a source of cheap human diet in many countries and it can be used as fresh products and commercial processed foods such as French fries and chip. Nevertheless potatoes cultivars differ in terms of their suitability for the production of processed products. The tuber specific gravity, dry matter and starch contents of a variety are critical features determining the quantity and quality of both products of industries (starch) and processed foods (French fries and chips). The present review conclude for French fry and chips industries, breeding for reduced sugar content, acceptable specific gravity, dry matter and starch contents is indispensable. Research efforts carried in Ethiopia related to processing quality were limited in their scope of quality parameters considered. The acceptability of potatoes for processing as French fries is largely dependent on the quality of the end products. Processing industry is totally dependent on the quality parameters of tuber to satisfy the increasing demand of consumers. Therefore, selection of varieties should not be limited only for high yield, but also for internal (specific gravity, dry matter, starch contents) and external quality (tuber shape, eye depth, tuber fresh color and tuber skin color) of tubers.

\section{References}

Andre, C.M., Ghislain, M., Bertin, P., Oufir, M., Rosario, H.M., Hoffmann, L., Hausma,J.F., Larondelle, Y. and Evers, D. (2007). Andean potato cultivars (Solanum tuberosum L.) as a source of antioxidant and mineral micronutrients. Journal of Agricultural and Food Chemistry, 55(2): 366-378.

Arslanoglu, F., Aytac, S. and Oner, K. (2011). Morphological characterization of the local potato (Solanum tuberosum L.) genotypes collected from the Eastern Black Sea region of Turkey. African Journal of Biotechnology, 10(6): 922-932.

Asmamaw, Y., Tsegaw, T. and Seyoum, T. (2010). Specific gravity, dry matter concentration, pH, and crispmaking potential of Ethiopian potato (Solanum tuberosum $\mathrm{L}$.) cultivars as influenced by growing environment and length of storage under ambient conditions. Potato Research, 53: 95-109.

Birch, P.R., Bryan, G., Fenton, B., Gilroy, E.M., Hein, I., Jones, J.T., Prashar, A., Taylor, M.A., Torrance, L. and Toth, I.K. (2012). Crops that feed the world 8: Potato: are the trends of increased global production sustainable?. Food Security, 4(4): 477-508. 
Bradshaw, J.E. and Ramsay, G. (2005). Utilisation of the commonwealth potato collection in potato breeding. Euphytica, 146(1-2): 9-19.

Brown, C.R. (2005). Antioxidants in potato. American Journal of Potato Research, 82(2): 163-172.

Buso, J.A., Boiteux, L.S. and Peloquin, S.J. Heterotic, (2000). Effects for yield and tuber solids and type of gene action for five traits in $4 \mathrm{x}$ potato families derived from interploid (4x-2x) crosses. Plant Breeding, 119(2): 111-117.

Camire, M.E., Kubow, S. and Donnelly, D.J. (2009). Potatoes and human health. Critical Reviews in Food Science and Nutrition, 49(10): 823-840.

Carputo, D., Aversano, R. and Frusciante, L. (2004). Breeding potato for quality traits. In: Meeting of the Physiology Section of the European Association for Potato Research, 684: 55-64.

Cuesta, S. (2013). Potato quality traits: variation and genetics in Ecuadorian potato landraces. Doctoral dissertation, Wageningen University, Wageningen.

Elfnesh, F., Tekalign, T. and Solomon, W. (2011). Processing quality of improved potato (Solanumtuberosum L.) cultivars as influenced by growing environment and blanching. African Journal of Food Science, 5(6): 324332.

Ezekiel, R., Singh, N., Sharma, S. and Kaur, A. (2013). Beneficial phytochemicals in potato a review. Food Research International, 50(2): 487-496.

Friedman, M. (1997).Chemistry, biochemistry, and dietary role of potato polyphenols. A review. Journal of Agricultural and Food Chemistry, 45(5): 1523-1540.

Gumul, D., Ziobro, R., Noga, M. and Sabat, R. (2011). Characterisation of five potato cultivars according to their nutritional and pro-health components. Acta scientiarum Polonorum Technologia Alimentaria, 10(1): 73-81.

Hancock, R.D., Morris, W.L., Ducreux, L.J., Morris, J.A., Usman, M., Verrall, S.R., Fuller, J., Simpson, C.G., Zhang, R., Hedley, P.E. and Taylor, M.A. (2014). Physiological, biochemical and molecular responses of the potato (Solanum tuberosum L.) plant to moderately elevated temperature. Plant Cell and Environment, 37(2): 439-450.

Hassanpanah, D., Hassanabadi, H. and Azizi Chakherchaman, S.H. (2011). Evaluation of cooking quality characteristics of advanced clones and potato cultivars. American Journal of Food Technology, 6(1): 72-79.

Haverkort, A.J. (2007). Potato crop response to radiation and day length, In: Vreugdenhil, D., Bradshaw, J., Gebhardt, C., Govers, F., Taylor, M.A., MacKerron, D.K. and Ros, H.A. (eds.), Potato Biology and Biotechnology: Advances and Perspectives. Elsevier, London.

Hawkes, J.G. and Francisco-Ortega, J. (1993). The early history of the potato in Europe. Euphytica, 70(1): 1-7.

Hawkes, J.G. (1990). The potato: evolution, biodiversity and genetic resources. Belhaven Press. Washington, D.C., p. 235 .

Hijmans, R.J. and Spooner, D.M. (2001). Geographic distribution of wild potato species. American Journal of Botany, 88(11): 2101-2112.

Hijmans, R.J., Gavrilenko, T., Stephenson, S., Bamberg, J., Salas, A. and Spooner, D.M. (2007). Geographical and environmental range expansion through polyploidy in wild potatoes (Solanum section Petota). Global Ecology and Biogeography, 16(4):485-495.

Huamán, Z. and Spooner, D.M. (2002). Reclassification of landrace populations of cultivated potatoes (Solanum sect.Petota). American Journal of Botany, 89(6): 947-965.

Hughes, J.C. (1974). Factors influencing the quality of ware potatoes. Potato Research, 17(4): 512-547.

Ismail, A., Abu, Z. and Wael, A. M. (2015). Growth and productivity of different potato varieties under Gaza Strip conditions. International Journal of Agriculture and Crop Sciences, 8(3): p. 433.

Jansky, S. (2000). Breeding for disease resistance in potato. Plant Breeding Reviews, 19: 69-155.

Jansky, S. (2009). Breeding, genetics and cultivar development, In: Singh J. and Kaur L. (eds.), Advances in potato chemistry and technology. Academic Press, Burlingto, VT.

Kaur, S. and Aggarwal, P. (2014). Studies on Indian potato genotypes for their processing and nutritional quality attributes. International Journal of Current Microbiology Applied Sciences, 3(8): 172-177.

Kirkman, M.A. (2007). Global markets for processed potato products, In: Vreugdenhil, D., Bradshaw, J., Gebhardt, C., Govers, F., Taylor, M.A., MacKerron, D.K. and Ross, H.A. (eds.), Potato Biology and Biotechnology, Advances and Perspectives. Elsevier, London.

Kozukue, N., Yoon, K.S., Byun, G.I., Misoo, S., Levin, C.E. and Friedman, M. (2008). Distribution of glycoalkaloids in potato tubers of 59 accessions of two wild and five cultivated Solanum species. Journal of Agricultural and Food Chemistry, 56(24): 11920-11928.

Kumar, D., Singh, B.P. and Kumar, P. (2004). An overview of the factors affecting sugar content of potatoes. Annals of Applied Biology, 145(3): 247-256.

Kyamanywa, S., Kashaija, I.N., Getu, E., Amata, R., Senkesha, N. and Kullaya, A. (2011). Enhancing food security through improved seed systems of appropriate varieties of cassava, potato and sweetpotato resilient to climate change in Eastern Africa. ILRI, Nairobi. 
Li, X.Q., De Jong, H., De Jong, D.M. and De Jong, W.S. (2005). Inheritance and genetic mapping of tuber eye depth in cultivated diploid potatoes. Theoretical and Applied Genetics, 110(6): 1068-1073.

Lutaladio, N. and Castaldi, L. (2009). Potato: The hidden treasure. Journal of Food Composition and Analysis, 22(6): 491-493.

Ovchinnikova, A., Krylova, E., Gavrilenko, T., Smekalova, T., Zhuk, M., Knapp, S. and Spooner, D.M. (2011). Taxonomy of cultivated potatoes (Solanum section Petota: Solanaceae). Botanical Journal of the Linnean Society, 165(2): 107-155.

Richards, T.J., Kagan, A. and Gao, X.M. (1997). Factors influencing changes in potato and potato substitute demand. Agricultural and Resource Economics Review, 26: 52-66.

Shirsat, S.G. and Thomas, P. (1998). Effect of irradiation and cooking methods on ascorbic acid levels of four potato cultivars. Journal of Food Science and Technology, 35(6): 509-514.

Simmonds, N.W. (1979). Principles of crop improvement. Longman, London.

Spooner, D.M. and Bamberg, J.B. (1994), Potato genetic resources: sources of resistance and systematics. American Potato Journal, 71(5): 325-337.

Spooner, D.M. and Salas, A. (2006). Structure, biosystematics, and genetic resources, In: Gopal, J. Khurana, S. M. P. (eds.), Handbook of Potato Production, Improvement, and Postharvest Management. Haworth's Press, Inc, New York.

Spooner, D.M., McLean, K., Ramsay, G., Waugh, R. and Bryan, G.J. (2005). A single domestication for potato based on multilocus amplified fragment length polymorphism genotyping. Proceedings of the National Academy of Sciences of the United States of America, 102(41): 14694-14699.

Spooner, D.M., Núñez, J., Trujillo, G., Rosario, H.M., Guzmán, F. and Ghislain, M. (2007). Extensive simple sequence repeat genotyping of potato landraces supports a major reevaluation of their gene pool structure and classification. Proceedings of the National Academy of Sciences of the United States of America, 104(49): 19398-19403.

Storey, M. (2007). The Harvested Crop, In: Vreugdenhil, D., Bradshaw, J., Gebhardt, C., Govers, F., Taylor, M.A., MacKerron, D.K. and Ross, H.A. (eds.), Potato Biology and Biotechnology: Advances and Perspectives. Elsevier, London.

Taylor, M.A., McDougall, G.J. and Stewart, D. (2007). Potato flavour and texture, In: Vreugdenhil, D., Bradshaw, J., Gebhardt, C., Govers, F., Taylor, M.A., MacKerron, D.K. and Ross, H.A. (eds.), Potato Biology and Biotechnology: Advances and Perspectives. Elsevier, London.

Tesfaye Abebe, Shermarl, W. and Thunya, T. (2012a). Evaluation of specific gravity of potato varieties in Ethiopia as a criterion for determining processing quality. Kasetsart Journal of Natural Science, 47: 30-41.

Tesfaye Abebe, Shermarl, W., Thunya, T. and Oranuch, L. (2012b). Dry matter content, starch content and starch yield variability and stability of potato varieties in Amhara Region of Ethiopia. Kasetsart Journal (Natural Science), 46(5): 671-671.

Van Eck, H. (2007). Genetics of morphological and tuber traits, In: Vreugdenhil, D., Bradshaw, J., Gebhardt, C., Govers, F., Taylor, M.A., MacKerron, D.K. and Ross, H.A. (eds.), Potato Biology and Biotechnology: Advances and Perspectives. Elsevier, London.

Van Eck, H.J., Jacobs, J.M., Stam, P., Ton, J., Stiekema, W.J. and Jacobsen, E. (1994). Multiple alleles for tuber shape in diploid potato detected by qualitative and quantitative genetic analysis using RFLPs. Genetics, 137(1): 303-309.

Wassu Mohammed. (2016). Specific gravity, dry matter content, and starch content of potato (Solanum tuberosum L.) varieties cultivated in Eastern Ethiopia. East African Journal of Science, 10(2): 87-102.

Werij, J.S., Furrer, H., Van Eck, H.J., Visser, R.G. and Bachem, C.W. (2012). A limited set of starch related genes explain several interrelated traits in potato. Euphytica, 186(2): 501-516.

Werij, J.S., Kloosterman, B., Celis-Gamboa, C., De Vos, C.R., America, T., Visser, R.G. and Bachem, C.W. (2007). Unravelling enzymatic discoloration in potato through a combined approach of candidate genes, QTL, and expression analysis. Theoretical and Applied Genetics, 115(2): 245-252.

Werij, J.S. (2011). Genetic analysis of potato tuber quality traits. Doctoral dissertation, Wageningen University. 